\title{
An Intragaleal Frontal Dermoid Cyst: A Location Never Reported
}

\author{
Aurélien Ndoumbe1,2*, Blaise Nkegoum ${ }^{3,4}$, Mathieu Motah1,5, Samuel Takongmo ${ }^{6,7}$ \\ ${ }^{1}$ Faculty of Medicine \& Pharmaceutical Sciences, University of Douala, Douala, Cameroon, \\ ${ }^{2}$ University Teaching Hospital of Yaounde, Yaounde, Cameroon \\ ${ }^{3}$ Faculty of Sciences, University of Dschang, Dschang, Cameroon \\ ${ }^{4}$ Service of Pathology, University Teaching Hospital of Yaounde, Yaounde, Cameroon \\ ${ }^{5}$ Service of Surgery, Douala General Hospital, Douala, Cameroon \\ ${ }^{6}$ Faculty of Medicine \& Biomedical Sciences, University of Yaoundé, Yaoundé, Cameroon \\ ${ }^{7}$ Head Service of Surgery, University Teaching Hospital of Yaounde, Yaounde, Cameroon \\ Email: ${ }^{*}$ aurelien.ndoumbe@gmail.com, aurelen@yahoo.fr, aurelien.ndoumbe@free.fr
}

Received 21 March 2014; revised 22 April 2014; accepted 24 May 2014

Copyright (C) 2014 by authors and Scientific Research Publishing Inc.

This work is licensed under the Creative Commons Attribution International License (CC BY). http://creativecommons.org/licenses/by/4.0/

\section{(c) (i) Open Access}

\begin{abstract}
All dermoid cysts arising at the cranial vault had been reported as being located subgaleally, i.e. under the galea aponeurotica or epicranium. We are presenting a case that we believe to be the first case of an intragaleal dermoid cyst ever reported. An eighteen years old girl presented at our consultation for a midline frontal swelling evolving since 2 years. Neurological examination was normal. The Computed Tomography (CT) scan showed a round shaped heterogeneous mass at the vertex with no intracranial extension. The lesion was excised surgically. It appeared to be located intragaleally (within the epicranium) and composed of hairs and liquefied fat evocative of a dermoid cyst. The diagnosis of dermoid cyst was confirmed on histology. Postoperative outcome was excellent and the patient is symptom-free 16 months after surgery.
\end{abstract}

\section{Keywords}

Dermoid Cyst, Galea Aponeurotica, Epicranium, Cranial Vault

\section{Introduction and Background}

Dermoid cysts also known as inclusion cysts are pseudotumors thought to arise from inclusion of ectodermal elements within other tissues during embryologic life or after a trauma [1]-[3]. They had been described in many

\footnotetext{
${ }^{*}$ Corresponding author.
}

How to cite this paper: Ndoumbe, A., Nkegoum, B., Motah, M. and Takongmo, S. (2014) An Intragaleal Frontal Dermoid Cyst: A Location Never Reported. Open Journal of Modern Neurosurgery, 4, 121-125. 
tissues, organs and locations in the human body [2]. Dermoid cysts of the head involve the neurocranium as well as the splanchnocranium (the face); they can be intra- or extra-axial in any possible location (intracranial, extracanial, intradural, extradural, intradiploic, whitindural sinuses or air sinuses, and so on) [1]-[18]. Those involving the cranial vault had been unanimously described as being located under the cranial vault aponeurosis also called galea aponeurotica or epicranium. Dermoid cysts over the anterior fontanelle seem to represent a particular entity of these lesions [1]. We are reporting on the first case of an intragaleal dermoid cyst ever described.

\section{Clinical Case}

An 18 years old girl presented at our consultation on October 2012. She was complaining of having a slow growing midline frontal swelling which appeared two years ago. She reported a mild head trauma at the age of 8 years. The swelling occurred many years after the trauma, but timing between the two events was impossible to establish. On physical examination, she had a bump in the middle of her forehead, behind the hairline. On palpation, the mass was not tender and adherent to superficial and deep tissues. Transillumination was negative. The swelling, thought to be an abscess, was incised at a dispensary a year ago but did not disappear in spite of long term antibiotics given. Neurological examination was normal. The plain X-rays showed flattening of frontal bone at the site of the mass. On Computed Tomography (CT) scan, the lesion appeared round shaped with a broad base, heterogeneous with some parts having the same density as brain tissue and others showing hypodensity similar to that of subcutaneous fat or air. In some slices it appeared as having a well defined capsule with trabeculae inserting it to the skin. The cranial vault appeared flattened on some slices. There was a slight ring enhancement with contrast injection (Figure 1). There was neither bone effraction nor intracranial extension. The lesion was removed surgically under general anesthesia with tracheal intubation. The patient was positioned on the back with her head resting on a horseshoe head holder. An incomplete bicoronal incision extending few centimeters at the lateral boundaries of the mass was done. The galea was swollen at the site of the lesion. The superficial sheet of the galea was divided from subcutaneous tissue. After the boundaries of the mass were clearly delimited, the galea was incised until the pericranium few centimeters away from the tumor's boundaries to avoid opening the cyst accidentally. The deeper sheet of the epicranium was then gently separated from the cranium with the index finger. This maneuver revealed absence of lesion under the galea although the tumor's print over the bone at the site of anterior fontanelle was visible. We therefore incised the galea at its posterior margin where it was previously divided. Hair and liquefied fat extruded from the lesion demonstrating the dermoid nature of the cyst. With further dissection, the cyst wall appeared as a thin shining whitish envelope embedded inside and not under the galea. We then excised the galea all around the cyst boundaries and gross total removal of the lesion was then achieved (Figure 2). The wound was closed in multilayers. The patient was discharged from the hospital on day two after surgery. Outcome was excellent and patient reported no complain at 16 months of follow up.

\section{Discussion}

Adeloye and Odeku [1] were the first to report on an important series of dermoid cysts of the anterior fontanelle in Nigerians. They noticed a female predominance with a sex ratio of 2:1. Dermoid cysts of the cranial vault were first believed to be located always at the anterior fontanelle and to arise only in black Africans. This had been proven to be wrong [12]-[14]. Dermoid cysts are not true neoplasms and their pathogenesis is not definitely established [5] [15]. These benign slow growing lesions are rare. They had been described in many tissues and organs but are more frequent in the skin and subcutaneous tissue. Those involving the head and the neck represent about $7 \%$ of all dermoids and $0.3 \%$ of all intracranial tumors [3]. Their location can be extracranial, intracranial, intraspinal, extradural, intradural, interdural, within the neuraxis, intradiploic, within air sinuses and so on [16]. Up to date, dermoid cysts of the cranial vault had been unanimously described as being located subgalealy i.e. under the galea aponeurotica. Some authors had used the term "subcutaneous" instead of subgaleal [15]. Our observation could be the first case of an intragaleal dermoid cyst ever reported. Concerning dermoid cysts of the cavernous sinus, they were described as extradural, intradural or parasellar lesions until Nakagawa first reported an interdural location [4].

Dermoid cysts of the cranial vault are most often located around the anterior fontanelle. Most of the time, they do not have intracranial extension as in our case. Clinically, they present as a swelling on top of the head with 


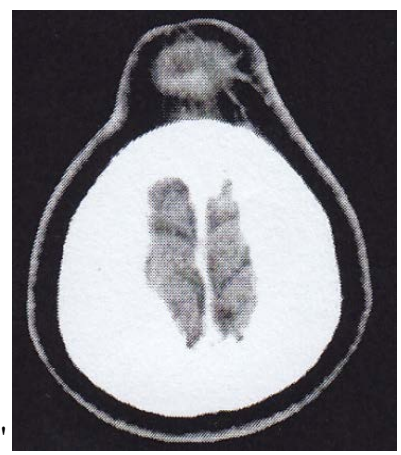

(a)

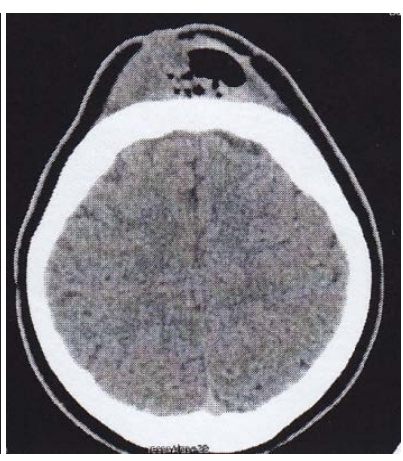

(b)

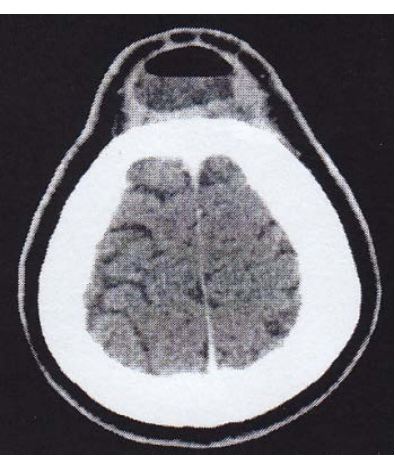

(c)

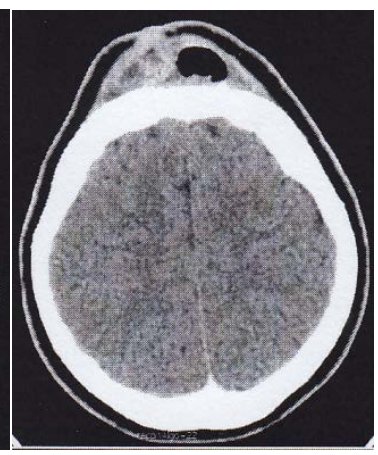

(d)

Figure 1. CT scan. (a) Round shape bump over the cranial vault; (b) Heterogenous lesion with solid and cystic parts with flattening of calvaria; (c) Slight ring enhancement after contrast injection; (d) Slight enhancement of the solid part. No intracranial extension.

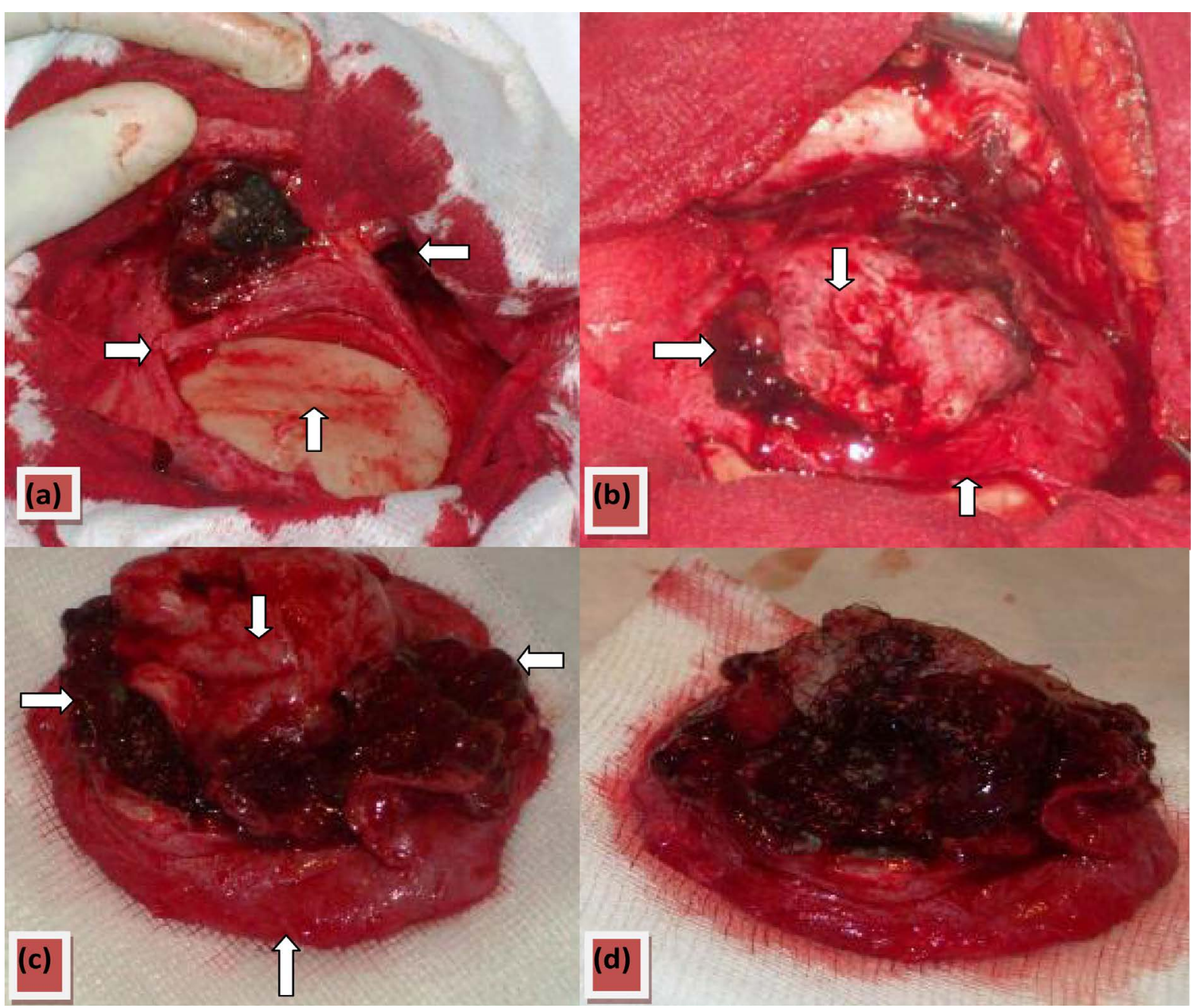

Figure 2. Operative pictures. (a) After exposure and incision of galea at the posterior boundary of lesion, it appeared that the lesion was not under the galea (vertical arrow) but within splittedepicranium (horizontal arrows); (b) After circular incision of galea, dermoid components (horizontal arrow) oosed out between superficial (downward arrow) and deep (upward arrow) aspects of epicranium; (c) Gross total removal of dermoid (horizontal arrows) after excision of epicranium. The dermoid was embedded within outer (downward arrow) and inner (upward arrow) sheets of split galea aponeurotica; (d) Dermoid cyst made of hair and fat. 


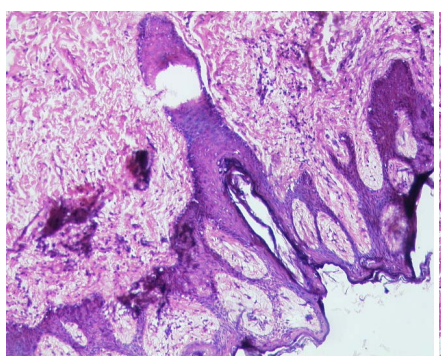

(a)

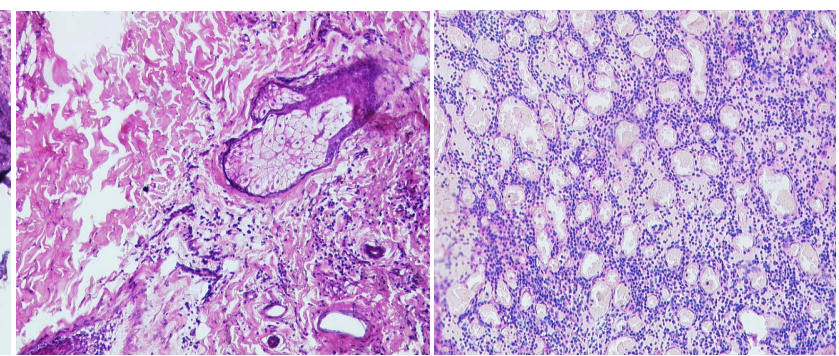

(b) (c)

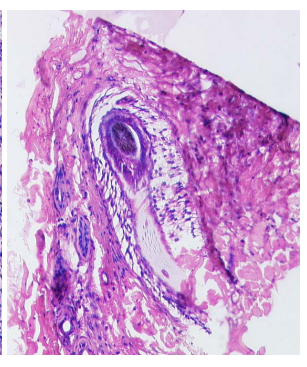

(d)

Figure 3. Histological patterns. (a) Stratified squamous epithelium with hair follicles, sebaceous and sweat glands with rich kera tinized stroma; (b) Cyst with adipocytes and keratin; (c) Numerous sweat glands; (d) Typical hair follicle.

out signs of increased intracranial pressure and neurological examination is normal.

For Adachi et al. [2], dermoid cysts can be classified into 3 categories: 1) congenital dermoid cysts of the teratoma type, derived from the embryonic epithelium and confined to the ovary or testis; 2) acquired implantation cysts formed by cells implanted traumatically into deeper structures; and 3) congenital dermoid inclusion cysts resulting from the inclusion of displaced dermal cells along the embryonic fusion line. Our case could be an acquired implatantion cyst because it was not present at birth or during childhood and the patient sustained a head trauma at the age of 8 . But this is questionable because there was no scar related to the head trauma at the site of the cyst and why does it take 10 years from time of trauma and appearance of the cyst? (Figure 3)

Because of possible intracranial extension and the need to rule out differential diagnoses like encephalocele, meningocele, hemangioma, sinus pericranii among others, Computed Tomography (CT) and Magnetic Resonance Imaging (MRI) are justified in the management of dermoid cysts of the cranial vault. Dermoid cysts appear as hypodense lesions on CT scan with no or slight contrast enhancement. On MRI, dermoid cysts appear as low-intensity lesions on diffusion weighted images; they are variable on T1WI and T2WI [2] [15]. MRI is crucial for visualizing the relationship between the cyst and intracranial structures such as the superior sagittal sinus, dura mater, and brain parenchyma. In our case, we did not perform an MRI exam because it was not available in our hospital.

Dermoid cysts are benign slow growing lesions for which surgical excision is the treatment of choice. Pryor et al. [12] operated 49 dermoid cysts of head and neck and had only one recurrence. For dermoid cysts of the cranial vault, complete surgical removal can be achieved in most cases and is curative as in our case and the postoperative course is favorable. Surgical excision of dermoid cysts of the cranial vault is made for cosmetic reasons. There is a controversy about spontaneous disappearance of dermoid cysts [1] [11]. Although rare, there is a possibility for malignant transformation into epidermoid carcinoma.

\section{Conclusion}

Dermoidcysts, had been described in most tissues and in various locations. Those involving the cranial vault had been unanimously described as being located under the galea aponeurotica or epicranium. Our case is interesting in that it could be the first case of an intragaleal dermoid cyst ever reported.

\section{Acknowledgements}

We thank M.M. for giving her consent for publication of her case.

\section{References}

[1] Adeloye, A. and Latunde Odeku, E. (1971) Congenital Subgaleal Cysts over the Anterior Fontanelle in Nigerians. Archives of Diseases in Childhood, 46, 95-98. http://dx.doi.org/10.1136/adc.46.245.95

[2] Adachi, K., Ishii, N., Takahashi, H. and Teramoto, A. (2012) Congenital Dermoid Cyst at the Anterior Fontanelle: Neuroimaging before and after Fontanelle Closure. Journal of Nippon Medical School, 79, 291-295. http://dx.doi.org/10.1272/jnms.79.291

[3] Velho, V.L., Khan, S.W., Agarwal, A. and Sharma, M. (2012) Intra-Axial CNS Dermoid Cyst. Asian Journal of Neurosurgery, 7, 42-44. 
[4] Rato, R.M.F., Pappamikail, L.B., Ratilal, B.O. and Luiz, C.V. (2012) Dermoid Tumor of the Lateral Wall of the Cavernous Sinus. Surgical Neurology International, 3, 10. http://dx.doi.org/10.4103/2152-7806.92180

[5] Al-Muhaimeed, H.S., Abdelwahed, H.Y., Elgamal, E.A., Alokby, G.M., Biannasser, A.M. and Ashraf, M.M. (2012) Extradural Dermoid Cyst of the Mastoid Bone: A Case Report. Case Reports in Otolaryngology, 2012, Article ID: 548340. http://dx.doi.org/10.1155/2012/548340

[6] Caldarelli, M., Massimi, L., Kondageski, C. and Di Rocco, C. (2004) Intracranial Midline Dermoid and Epidermoid Cysts in Children. Journal of Neurosurgery, 100, 473-480.

[7] De Carvalho, G.I., Fagundes-Pereyra, W.J., Marques, J.A., Dantas, F.L. and De Sousa, A.A. (2001) Congenital Inclusion Cysts of the Anterior Fontanelle. Surgical Neurology, 56, 400-405. http://dx.doi.org/10.1016/S0090-3019(01)00621-8

[8] Gormley, W.B., Tomecek, F.J., Qureshi, N. and Malik, G.M. (1994) Craniocerebral Epidermoid and Dermoid Tumours: A Review of 32 Cases. Acta Neurochirurgica (Wien), 128, 115-121. http://dx.doi.org/10.1007/BF01400660

[9] Hashiguchi, K., Morioka, T., Yokohama, N., Mihara, F. and Sasaki, T. (2005) Subgaleal Dermoid Tumors at the Anteriror Fontanelle. Pediatric Neurosurgery, 41, 54-57. http://dx.doi.org/10.1159/000084868

[10] Chater-Cure, G., Hoffman, C., Knopman, J., Rhee, S. and Souweidane, M.M. (2011) Endoscopy-Assisted Removal of Periorbital Inclusion Cysts in Children. Journal of Neurosurgery: Pediatrics, 7, 161-164.

[11] Maurice, S.M. and Burstein, F.D. (2012) Disappearing Dermoid: Fact or Fiction? Journal of Craniofacial Surgery, 23, 31-33. http://dx.doi.org/10.1097/SCS.0b013e3182420981

[12] Pryor, S.G., Lewis, J.E., Weaver, A.L. and Orvidas, L.J. (2005) Pedriatric Dermoid Cysts of the Head and Neck. Otolaryngology—Head and Neck Surgery, 132, 938-942. http://dx.doi.org/10.1016/j.otohns.2005.03.005

[13] Nicolau, A., Daney, I., Diard, F., Risch, M. and Kind, M. (1986) Midline Subepicranial (Subgaleal) Dermoid Cysts in Children. Report of 6 Cases and Review of the Literature. Annales de Radiologie (Paris), 29, 511-518.

[14] Chaudhari, A.B., Rosenthal, A.D. and Lippa, S. (1984) Congenital Inclusion Cysts of the Subgaleal Space. Surgical Neurology, 21, 61-66. http://dx.doi.org/10.1016/0090-3019(84)90403-8

[15] Sorenson, E.P., Powell, J.E., Rozelle, C.J., Tubbs, R.S. and Loukas, M. (2013) Scalp Dermoids: A Review of Their Anatomy, Diagnosis and Treatment. Child's Nervous System, 29, 375-380. http://dx.doi.org/10.1007/s00381-012-1946-y

[16] Liu, H., Zhang, J.N. and Zhu, T. (2012) Microsurgical Treatment of Spinal Epidermoid and Dermoid Cysts in the Lumbosacral Region. Journal of Clinical Neuroscience, 19, 712-717. http://dx.doi.org/10.1016/j.jocn.2011.07.046

[17] Wood, J., Couture, D. and David, L.R. (2012) Midline Dermoid Cyst Resulting in Frontal Bone Erosion. Journal of Craniofacial Surgery, 23, 131-134. http://dx.doi.org/10.1097/SCS.0b013e318240fe5e

[18] Patnaik, A., Mishra, S.S. and Senapati, S.B. (2012) Giant Intradiploic Cyst of the Frontal Bone Sinus in an Eldery. Neurology India, 69, 542-543. http://dx.doi.org/10.4103/0028-3886.103218 
Scientific Research Publishing (SCIRP) is one of the largest Open Access journal publishers. It is currently publishing more than 200 open access, online, peer-reviewed journals covering a wide range of academic disciplines. SCIRP serves the worldwide academic communities and contributes to the progress and application of science with its publication.

Other selected journals from SCIRP are listed as below. Submit your manuscript to us via either submit@scirp.org or Online Submission Portal.
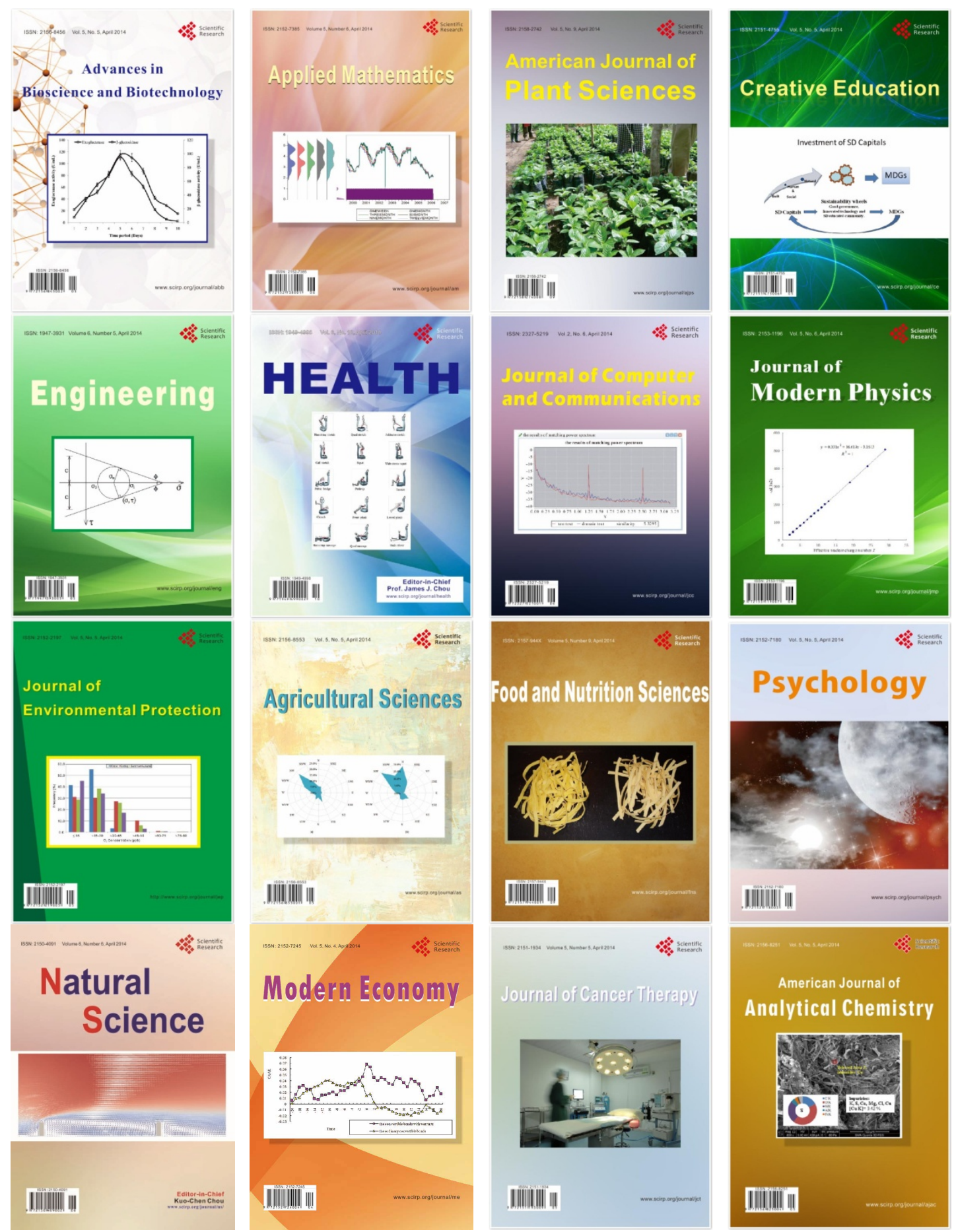